\begin{tabular}{|c|c|c|}
\hline & Int.J.Curr.Microbiol.App.Sci (2021) 10(09): 18-23 & \multirow{4}{*}{ 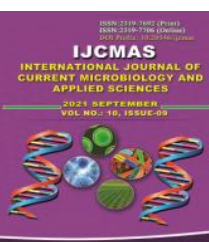 } \\
\hline & \multirow{4}{*}{$\begin{array}{l}\text { International Journal of Current Microbiology and Applied Sciences } \\
\text { ISSN: 2319-7706 Volume } 10 \text { Number } 09 \text { (2021) } \\
\text { Journal homepage: http://www.ijcmas.com }\end{array}$} & \\
\hline & & \\
\hline \begin{tabular}{|l} 
EXCELLENT \\
\end{tabular} & & \\
\hline PUBLIS & & www.ijemas.com \\
\hline
\end{tabular}

\title{
Analysis of TNF- $\alpha$ and IL-4 Levels with Soil Transmitted Helminth Infection in Adults In Pasie Nan Tigo Village 2020
}

\author{
Yanti Rahayu ${ }^{1}$, Nuzulia Irawati ${ }^{1,2 *}$ and Hirowati Ali ${ }^{1,3,4}$ \\ ${ }^{1}$ Magister of Biomedical Study Programs, ${ }^{2}$ Departement of Parasitology, \\ ${ }^{3}$ Department of Biochemistry, ${ }^{4}$ Biomedical Laboratory/Center for Integrative Biomedical \\ Research, Faculty of Medicine Andalas University, Padang, 25127, Indonesia \\ *Corresponding author
}

\section{A B S T R A C T}

Keywords

Poverty, poor hygiene, sanitation, infection

Article Info

Accepted:

05 August 2021

Available Online:

10 September 2021
Intestinal helminth infections are caused by soil-transmitted helminths (STH). Worm infections are classified as neglected diseases, namely infections that are not noticed and are chronic diseases, rarely cause clear clinical symptoms and the impact is only seen in the long term. STH infection affects the immune response in humans in the form of increased levels of immunoglobulin $\mathrm{E}$ ( $\mathrm{IgE}$ ), eosinophilia and production of $\mathrm{t}$ helper 2 (Th2), especially to changes in TNF- $\alpha$ and IL-4 levels. The purpose of this study was to determine the analysis of TNF- $\alpha$ and IL-4 levels with soil-transmitted helminths infection in adults. The research design used was case control, with a multistage-random sampling technique. Stool samples were taken from 127 adults and 24 subjects (18.9\%) were infected with STH using the kato katz examination method. Furthermore, 24 STH-infected subjects and 24 healthy control subjects were taken using enzyme-linked immunosorbent assay (ELISA). The study population was male and female adults aged 20-60 years as many as 48 people. The data was carried out by independent t-test $(\mathrm{p}<0.05)$ and it was considered that there was a significant relationship. c. The results showed that there was a significant difference in TNFlevels in adults in the STH-infected group and healthy yangiene with $\mathrm{p}$ value $=0.001$ and there was a significant difference in IL-4 levels in adults in the STH-infected group with $\mathrm{p}$ value $=0.001$. The conclusion of this study is that there are differences in TNF- levels lower in STH-infected people than healthy controls and higher IL-4 in STH-infected people than healthy controls in adults.

\section{Introduction}

Worm infection is a disease that threatens the health of the world's population in several developing countries, such as in Sub-Saharan Africa and the Asian region (Hotez, 2008). Parasitic infections can be associated with poverty, poor hygiene and sanitation. (Ni 
Made Nurhayati, 2018) Indonesia is one of the developing countries that has a high prevalence of helminth infections. (Rosyidah and Prasetyo, 2018). Soil Transmitted Helminths (STH) infection that can infect humans Ascaris lumbricoides, Trichuris trichiura, Necator americanus and Ancylostoma duodenale (Pasaribu, 2019).

Data on the prevalence of infection due to STH in 27 selected provinces reached $13.9 \%$ in 2012 (Ministry of Health, 2012). West Sumatra was ranked second with a prevalence of $82.3 \%$ (West Sumatra Provincial Health Office, 2012). After West Nusa Tenggara with a prevalence of $83.6 \%$ (Renanti, Rusjdi and Elmatris, 2015). Based on the Data Profile of the Padang City Health Office, it was stated that in 2012 to 2015, the incidence of STH infection was still quite high with the most sufferers being school-age children, but it did not rule out the possibility of STH infection being suffered by adults aged 20-60 years (WHO, 2018).

STH infections often attack children, but it is possible for STH infections to be suffered by adults aged 20-60 years (WHO, 2018). In children it can cause losses such as anemia, decreased physical health, and cognitive and memory decline (Palaban et al., 2018). In addition, STH infection can also occur in adults with varying symptoms (Ministry of Health, 2017).

In STH infection there are two immune responses, namely acute immune response and chronic immune response. Acute immune response is an immune response that plays a role when new STH infects humans. The chronic immune response is an immune response that plays a role when the acute immune response is unable to eliminate STH (Gazzineli, 2018). This immune response is characterized by increased activation of $\mathrm{T}$ helper 2 (Th2) cells, namely Interleukin-4 (IL-
4), Interleukin- 5 (IL-5), Interleukin-13 (IL13) and eosinophils. This immune response occurs as the body continues to be exposed to STH and the substances it secretes. Both of these exposures make Th2 cells over-activated and will suppress the immune response generated by T-helper 1 (Th1) and will activate T-regulatory cells. Treg cells will reduce the excessive immune response so that the body will be hyporesponsive to the presence of STH, so that these parasites will reproduce in the long term in the human body. (Gazzinelli, 2018).

This is supported by research conducted by Elfred (2016) which was conducted on two groups of farmers in Surabaya, namely the group infected with STH and not infected with STH. 0.059).

This is because the infection that has occurred in farmers has been going on for a long time and continuously so that $\operatorname{IgE}$ levels are not too high and not too strong to activate basophils and Th2 so that they are unable to produce TNF- mediators that are strong enough for worm expulsion.

Based on another study conducted by Naglaa (2016) conducted in Egypt, where research was conducted on the effect of Ascaris lumbricoides STH infection on cytokines, namely IL-4, IL-5 and TNF- $\alpha$. The results of this study indicate that there is a relationship between A. lumbricoides infection with high levels of infection in IL-4, IL-5 and TNF.

Based on the above background, the researcher then needs to conduct a study to find out whether there is an analysis of TNFand IL-4 levels with Soil Transmitted Helminths infection in adults in the city of Padang. Because if STH infection has an effect on TNF- $\alpha$ and IL-4 levels, further research can be carried out to be able to develop STH. 


\section{Materials and Methods}

This study uses a Case Control design, with a Multistage Random Sampling sampling technique that takes place from January 2020 to November 2020 in one of the villages in Padang City, Pasie Nan Tigo Village. The population in this study were adult men and women aged 20-60 years and domiciled in Pasie Nan Tigo Village, Padang City. Data in the form of general characteristics were obtained through interviews, while stool examination data were obtained from parasitological examinations at the Parasitology Laboratory of the Faculty of Medicine, Andalas University, and data for examination of TNF- $\alpha$ and IL-4 levels were obtained using the Enzyme-Linked Immunosorbent Assay (ELISA) method conducted at the Laboratory West Sumatra Provincial Health Office.

Stool samples were obtained from 127 adults who were willing to be research subjects by signing an informed consent. The results of stool examination on 127 research subjects showed that 24 of them were infected with STH (18.9\%). So, based on the large sample formula used, the STH-infected group and the healthy control group were used as a comparison by matching age and sex between the two groups. Then, the research subjects in both groups were taken blood serum to measure the levels of TNF- $\alpha$ and IL-4.

Normality test was carried out on data with a ratio measuring scale, namely TNF- and IL-4 levels in two groups (STH-infected and nonSTH-infected groups) using the Saphiro Wilk test, to see whether the data were normal or not, if the data were normally distributed, conducted by independent $t$-test, but if it is not normal the data is carried out with a nonparametric test, namely the Mann Whitney test to see if there are differences in the two variables to be tested.

\section{Results and Discussion}

Most of the research subjects were women, with the highest age range being 38-50 years. The types of STH that infect research subjects are T. trichiura (87.5\%), and A. lumbricoides $(12.5 \%)$ in table 1.

The average TNF- $\alpha$ and IL-4 levels in the STH-infected group were the highest percentage of Trichuris trichuria worms (87.5\%) compared to Ascaris lumbricoides $(12.5 \%)$.

The dependent and independent variables were assessed using the t-independent test, which found the STH-infected group at lower TNF- levels than the healthy control group and the IL-4 level in the STH-infected group was higher than the healthy control. However, the statistical test results found a significant relationship $(\mathrm{p}=0.001)($ Table 3$)$.

In this study, groups infected with STH tend to cause nutritional disorders and growth disorders, which can also cause the body's immune response (Rusjdi, 2012). By causing an immune response in humans in the form of increased levels of Immunoglobulin E (IgE), eosinophilia and increased production of cytokine T-helper 2 (Th2) peripheral blood leukocytes in response to stimulation of parasitic antigens (Bethony et al., 2006). In allergen infection, IgE attached to mast cells releases inflammatory mediators such as histamine, leukotrienes, chemokines and cytokines (IL-1, TNF- $\alpha$ ). (Moreau, 2009). The researchers found that the levels of TNF- $\alpha$ in the STH-infected group were lower than the healthy control group, which was statistically significant. 
Table.1 Characteristics of Research Subjects

\begin{tabular}{|c|c|c|c|c|}
\hline Characteristics of respondents & \multicolumn{2}{|c|}{$\begin{array}{c}\text { Group infected } \\
\text { with STH } \\
\text { (n= 24) }\end{array}$} & \multicolumn{2}{|c|}{$\begin{array}{c}\text { Group healthy } \\
\text { control } \\
(\mathbf{n}=\mathbf{2 4})\end{array}$} \\
\cline { 2 - 5 } & \multicolumn{2}{|c|}{$\mathbf{f}$} & $\mathbf{\%}$ & $\%$ \\
\hline Education & & & & \\
\hline Primary school & 5 & 20,8 & 7 & 29,2 \\
\hline Junior high school & 12 & 50,0 & 11 & 45,8 \\
\hline Senior high school & 7 & 29,2 & 5 & 20,8 \\
\hline College & 0 & 0 & 1 & 4,2 \\
\hline Work & & & & \\
\hline work & 9 & 37,5 & 6 & 25,0 \\
\hline Not working & 15 & 62,5 & 18 & 75,0 \\
Gender & & & & \\
\hline Woman & 15 & 62,5 & 4 & 16,7 \\
Man & 9 & 37,5 & 20 & 83,3 \\
\hline Respondent Age (Mean \pm SD) & $38.08 \pm 12.15$ & $42.08 \pm 9.60$ \\
\hline
\end{tabular}

Table.2 Frequency Distribution of STH .

\begin{tabular}{|c|c|c|}
\hline \multirow{2}{*}{ STH type } & \multicolumn{2}{|c|}{ STH Infected Group (n = 24) } \\
\cline { 2 - 3 } & F & \% \\
\hline Trichuris trichuria & 21 & 87,5 \\
\hline Ascaris lumbricoides & 3 & 12,5 \\
\hline
\end{tabular}

Table.3 Analysis of TNF- $\alpha$ and IL-4 .

\begin{tabular}{|c|c|c|c|}
\hline Variable & $\begin{array}{c}\text { STH Infected Group } \\
(\mathbf{n = 2 4})\end{array}$ & $\begin{array}{c}\text { Healthy control group } \\
(\mathbf{n}=\mathbf{2 4})\end{array}$ & $\boldsymbol{p}$ value \\
\hline TNF- $\boldsymbol{\alpha}$ level & $13,23 \pm 1,98$ & $29,39 \pm 7,86$ & 0,001 \\
\hline Mean \pm SD $(\mathbf{p g} / \mathbf{m l})$ & & & 0,001 \\
\hline IL-4 level & $206.44 \pm 32.43$ & $117.00 \pm 12.76$ & \\
\hline Mean \pm SD $(\mathbf{p g} / \mathbf{m l})$ & & & \\
\hline
\end{tabular}

This is in line with research conducted by Elfred (2016), where the value of TNF- $\alpha$ levels in the STH-infected group was lower than the healthy control group. The levels of IL-4 in the STH-infected group were higher than the healthy control group, which was statistically significant lower. this is in line with research conducted by Cooper (2008) and Naglaa (2016), where the value of IL-4 levels in the STH-infected group was higher than the lower healthy control group. That way, it can be interpreted that the research results obtained are consistent with previous research. The results showed that the differences in TNF- and IL-4 levels, as well as the analysis of TNF- $\alpha$ and IL-4 levels with Soil Transmitted Helminths infection in adults were statistically significant. This is possible 
because many factors affect the levels of TNF$\alpha$ and IL-4 such as caused by the different immunity of each respondent (Elfred, 2016) and because the infection lasts for a long time and continues so that $\mathrm{IgE}$ levels are not too high and not too strong. to activate mast cells and basophils so that basophils cannot produce TNF- and IL-4 mediators that are strong enough to expel worms. (Elfred, 2016). STH infection often becomes a chronic infection. STH infection induces an immune response of T Helper 2 (Th2) cells and regulatory $\mathrm{T}$ cells compared to Th1 cells, so the levels of proinflammatory cytokines normally produced by Th1 cells will also decrease (Wiria et al., 2014). STH infection can also activate regulatory $\mathrm{T}$ cells, $\mathrm{B}$ cells and AAM (Alternatively Activated Macrophage), where the activation of these cells further stimulates the secretion of IL-10 and TGF- $\beta$, IgG4 production and suppresses the work of mast cells, basophils, and eosinophils which results in on the reduction of the systemic inflammatory immune response in the host.

In the end, in the presence of chronic STH infection, the host immune system tends to be in an anti-inflammatory state, so that it will reduce the body's systemic inflammatory process which has an effect on increasing insulin sensitivity (Motran et al., 2018). There are differences in the levels of TNF- and IL-4 in people infected with STH and those who are not infected with STH in adults in the village of Pasie Nan Tigo, Padang City.

\section{Acknowledgement}

The researchers would like to thank the Faculty of Medicine, Andalas University, SubPuskesmas for Pasie Nan Tigo, Padang City, health cadres, Analysts of the Parasitology Laboratory of the Faculty of Medicine, Andalas University and the Laboratory of the Health Service of West Sumatra province and all research subjects who have participated

\section{References}

Bethony, J., et al., 2006. Soil-transmitted helminth infections: ascariasis, trichuriasis, and hookworm. Lancet. 367. pp. 1521-32.

Cooper, P. J., et al., 2008. Human infection with Ascaris lumbricoides is associated with a polarized cytokine response. The Journal of infectious diseases, 182(4), pp. 1207-1213.

Dinas Kesehatan Provinsi Sumatera Barat. 2012. Rekap Hasil Skrening Kesehatan Masyarakat Terkait Penyakit Infeksi Sumatera Barat Tahun 2012.

Elfred, et al., 2016. Gambaran Basofil, TNF$\alpha$, dan IL-9 Pada Petani Terinfeksi STH di kabupaten Kediri. Jurnal Biosains Pascasarjana Vol. 18 (2016) pp, Surabaya: Universitas Airlangga

Gazzinelli-Guimaraes,P.H, et al., 2018. Helminths Parasites and Immune Regulation. F1000Research. 7:1685

Hotez, et al., 2008. Soil-transmitted helminth infections : ascariasis, trichuriasis, and hookworm. pp. 1521-367

Kemenkes. 2012. Peraturan Menteri Kesehatan Republik Indonesia Tentang Penanggulangan Kecacingan. Jakarta: Kemeterian Kesehatan Republik Indonesia

Kementerian Kesehatan. (2017). PMK No.15 tentang Penanggulangan Cacingan.

Motran, C. C., Silvane, L,. Chiapello, L. S., Theumer, M. G., et al., (2018) 'Helminth infections: Recognition and modulation of the immune response by innate immune cells', Frontiers in Immunology, 9(APR), pp. 1- 12. doi: 10.3389/fimmu.2018.00664.

Naglaa., et al.,. 2016. Effect of Ascaris lumbricoides infection on $\mathrm{T}$ helper cell type 2 in rural Egyptian children. Journal of Therapeutics and Clinical Risk Management. 2016: 12 379-385. Egypt: Mansoura University Children 
Hospital

Ni Made Nuryanti, I. M. S. (2018) 'Soil Transmitted Helminths Infection in Elementary School', Jurnal Kesehatan Masyarakat, 13(3), pp. 323-330. doi: https://doi. org/10.15294/ kemas.v13i3.6507.

Pasaribu AP, et al., 2019. Prevalence and Risk Factors of Soil-transmitted Helminthiasis among School Children Living in an Agricultural Area of North Sumatera, Indonesia. BMC Public Health. 2019;19:1066.

Pabalan, N., Singian, E., Tabangay, L., Jarjanazi, H., et al., (2018) 'Soiltransmitted helminth infection, loss of education and cognitive impairment in school-aged children: A systematic review and meta-analysis', PLOS Neglected Tropical Diseases, 12(1), pp. 1-31. doi: https://doi.org/ 10.1371/journal.pntd.0005523.

Renanti, R., Rusjdi, S. R. and Elmatris (2015) 'Hubungan Infeksi Soil Transmitted Helminth dengan Status Gizi pada Murid SDN 29 Purus Padang', Jurnal
Kesehatan Andalas, 4(2), pp. 353-358. doi: 10.25077/jka.v4i2.253.

Rosyidah, H. N., Prasetyo, H. (2018) 'Prevalence of Intestinal Helminthiasis in Children at North Keputran Surabaya at 2017', Journal of Vocational Health Studies, 01, pp. 117-120. doi: 10.20473/jvhs. v1i1.2018.117-120.

Rusjdi, S. R. et al., 2012. Pengaruh infeksi cacing usus terhadap ekspresi interferon gamma serum paksa pemberian imunisasi tetanus toxoid. Majalah Kedokteran Andalas. 36(1): pp. 89-94.

World health organization, 2018, Deworning in children, retrieved april 12, 2018, from http://www.who.int/elena/titles/deworn ing/en/

Wiria, A. E., Sartono, E., Supali, T., Yazdanbakhsh, M. (2014) 'Helminth Infections, Type-2 Immune Response, and Metabolic Syndrome', Plos pathogens, 10(7), pp. 1-5. doi: 10.1371/journal.ppat.1004140.

\section{How to cite this article:}

Yanti Rahayu, Nuzulia Irawati and Hirowati Ali. 2021. Analysis of TNF- $\alpha$ and IL-4 Levels with Soil Transmitted Helminth Infection in Adults In Pasie Nan Tigo Village 2020. Int.J.Curr.Microbiol.App.Sci. 10(09): 18-23. doi: https://doi.org/10.20546/ijcmas.2021.1009.003 